\title{
Vertical Electrical Sounding (VES) for Estimation of Hydraulic Parameters in the Porous Aquifer
}

\author{
Andreia de Almeida ${ }^{1, *}$, , Daiane Ferreira Maciel ${ }^{2}$, Karen Félix Sousa ${ }^{2}$, Carlos Tadeu Carvalho Nascimento ${ }^{2}$ \\ and Sérgio Koide ${ }^{1}$ (D) \\ 1 Departamento de Engenharia Civil e Ambiental, Faculdade de Tecnologia, Universidade de Brasília, \\ 70910-900 Brasília, Brazil; skoide@unb.br \\ 2 Faculdade UnB Planaltina, Universidade de Brasília, 73345-010 Planaltina, Brazil; \\ daianefemaciel@gmail.com (D.F.M.); karenfelix.s25@gmail.com (K.F.S.); carlostadeu@unb.br (C.T.C.N.) \\ * Correspondence: andreiaalmeida.df@gmail.com
}

Citation: de Almeida, A.; Maciel, D.F.; Sousa, K.F.; Nascimento, C.T.C.; Koide, S. Vertical Electrical Sounding (VES) for Estimation of Hydraulic Parameters in the Porous Aquifer. Water 2021, 13, 170. https://doi.org/ 10.3390/w13020170

Received: 25 November 2020

Accepted: 8 January 2021

Published: 13 January 2021

Publisher's Note: MDPI stays neutral with regard to jurisdictional clai$\mathrm{ms}$ in published maps and institutional affiliations.

Copyright: $(\odot 2021$ by the authors. Licensee MDPI, Basel, Switzerland. This article is an open access article distributed under the terms and conditions of the Creative Commons Attribution (CC BY) license (https:// creativecommons.org/licenses/by/ $4.0 /)$.

\begin{abstract}
Similarities in both water and electric current flows allow the relation of hydraulic and geoelectric parameters of porous aquifers. Based on this assumption and the importance of the hydraulic parameters for groundwater analyses, this study aimed to estimate hydraulic conductivity (K) and transmissivity (T) with vertical electrical sounding (VES) in the porous aquifer at the experimental farm of the University of Brasilia, Brazil. VES is a geophysical technique that provides electrical resistivity $(\rho, \Omega \mathrm{m})$ and thickness $(\mathrm{h})$ of the subsurface layers. The $\rho$ and h aquifer data, associated with lithology, water table level (WTL), and groundwater electrical resistivity $\left(\rho_{\mathrm{w}}, \Omega \mathrm{m}\right)$, allowed the calculation of complementary geoelectric parameters (formation factor, F, and Dar Zarrouk parameters) and the relation with $\mathrm{K}$ and $\mathrm{T}$, determined via slug test. VES data allowed the elaboration of geoelectric models, with mean absolute percentage error (MAPE) below 6\% compared to field data, and the identification of the aquifer in each VES station. Significant exponential regression models $\left(\mathrm{R}^{2}>0.5\right.$ and $p$-value $\left.<0.05\right)$ showed the possibility of using geoelectric parameters to estimate hydraulic parameters. This study allowed the verification of the applicability of consolidated models and the identification of appropriate empirical relationships for hydrogeological characterization in the Brazilian tropical porous aquifers. The results of this work, besides the rapid sampling and low cost of performing vertical electrical sounding (VES), may justify the use of this geophysical technique for preliminary porous aquifer characterization, especially in regions absent of or with insufficient monitoring wells.
\end{abstract}

Keywords: electrical resistivity; hydraulic conductivity; transmissivity; Brazil

\section{Introduction}

The resolution of flow and transport problems in aquifers depends on information about the hydraulic parameters, which influence the occurrence and movement of groundwater. Considered the most important parameter in hydrogeological studies, hydraulic conductivity $(\mathrm{K})$ indicates the ability of aquifers to conduct water $[1,2]$. The amount of water transmitted horizontally throughout the aquifer thickness (h) equals transmissivity $(T)$, generically represented as the product between $K$ and $h[1,3]$. However, despite the importance for groundwater assessment and management, information about $\mathrm{K}$ and $\mathrm{T}$ values are scarce due to limitations in field data acquisition $[2,4,5]$.

Traditionally, determining aquifer hydraulic parameters requires the use of field hydrogeological methods (e.g., pumping or slug test) characterized by a high demand for time and financial resources [5-7]. As an alternative, geoelectric measurements from the soil surface by DC (direct current) electric geophysical method, applied especially through the vertical electrical sounding (VES) technique, enable a non-invasive and relatively inexpensive hydrogeological characterization [2,8-14]. In addition to applications for identifying soil moisture content, lithological structures, and water table level (WTL) [15-18], surface 
geoelectrical measurements have allowed indirect estimation of $\mathrm{K}$ and $\mathrm{T}$, reducing the need to drill boreholes [12-14,17,19-22].

Similarities between water flow and electrical current are the basic assumption for establishing relationships between electrical and hydraulic behavior in a porous medium $[4,10,11,23]$. Considering that both the electric current and the water follow the path of least resistance, at the level of the pores the electrical path is similar to the hydraulic path. Therefore, the electrical resistivity $(\rho=1 / \sigma, \sigma=$ electrical conductivity) should reflect an inverse relationship with $\mathrm{K}$ and $\mathrm{T}[4,6,18,19,21,24]$. In this way, Heigold et al. [24] proposed an inverse exponential relationship between aquifer resistivity $\left(\rho_{\text {aquifer }}\right)$, identified by VES, and K, determined by pumping and slug tests, which are widely used in current studies for sand and gravel porous aquifers (also called granular aquifers) [12,25-27].

Besides that, aquifer properties have been estimated using geoelectric parameters derived from $\rho$ as the formation factor $(F)$ and the Dar Zarrouk parameters (longitudinal conductance, $C$, and transverse resistance, $\mathrm{R})$. The formation factor $(\mathrm{F})$ maintains a relationship with the hydraulic parameters because, according to Archie's first law, it has an inverse relationship with the porosity [10,20,23,28]. According to Mazac et al. [29], the inverse regression model between $\mathrm{F}$ and $\mathrm{K}$, as well as between $\rho$ and $\mathrm{K}$, predominates in homogeneous sediments, where $K$ is dependent primarily on effective porosity $[20,23,28,30]$. Instead, direct relationship can occur if $\rho$ changes, and consequently $\mathrm{F}$ changes, are controlled by variations in soil percent clay $[2,24,28,29,31]$.

Exploiting the Dar Zarrouk parameters $(C=h / \rho=h \times \sigma$ and $R=h \times \rho=h / \sigma)$ [11], several empirical equations have been developed to convert $C$ and $R$ into transmissivity $[2,14,32,33]$. For instance, Hasan et al. [32], considering a directly proportional empirical relationship, estimated $\mathrm{T}$ value from $\mathrm{R}$ data for an unconfined aquifer, composed of complex alluvial material (sand, gravel with sand, clay with sand, and smaller clay) in Pakistan. However, there are also inverse empirical relationships describing the relationship between $\mathrm{T}, \mathrm{C}$, and R [33]. In addition to empirical models, Niwas and Singhal [8] established an analytical relationship combining the transmissivity $(\mathrm{T}=\mathrm{K} \times \mathrm{h})$ and both Dar Zarrouk parameters. By deduction, when $\mathrm{K}$ and $\rho$ are inversely related, $\mathrm{T}$ and $\mathrm{C}$ are proportional; in cases where $\mathrm{K}$ and $\rho$ are directly related, $\mathrm{T}$ is proportional to $\mathrm{R}[2,8,14,34,35]$.

Even though there are consolidated models in the scientific literature, the estimation of hydraulic parameters from geoelectrical measurements, especially based on empirical relationships, can provide reliable predictions under specific conditions. Variations in the percentage of saturation and in the constituent material between different aquifers can result in uncertainties related to the significance and the predominant direction (direct or reverse) of the empirical models $[2,6,17,26,28]$. Analytical models, as highlighted by Niwas and Singha [8], are also elaborated for an area with a particular setting. Thus, models proposed under specific hydrogeophysical features need validation before being generalized $[6,24,28,36]$.

Due to the limitations on generalizing the current empirical and analytical models and the reduced availability of studies that consider applied geophysics to the estimation of hydraulic parameters in Brazilian tropical soils [21,22], we compare geoelectrical and hydraulic parameters calculated from VES and slug test, respectively, for an unconfined granular aquifer. The objective of this study was to identify significant relationships between $\mathrm{K}, \mathrm{T}$, and geoelectric measurements derived from VES ( $\rho_{\text {aquifer }}, \mathrm{F}$, and Dar Zarrouk parameters), providing the indirect estimation of porous aquifer hydraulic parameters in Central Brazil.

\section{Materials and Methods}

\subsection{Study Area}

The study area was the Fazenda Água Limpa (FAL), which is the University of Brasilia experimental farm, located in the southern portion of the Distrito Federal, Brazil $(8,229,000$ to 8,238,000 UTM N and 180,000 to 190,000 UTM E, SIRGAS 2000 Datum) (Figure 1). The climate in the study area is tropical Aw, defined by Koppen as typical of savannah, 
with monthly average temperature and evapotranspiration equal to $22{ }^{\circ} \mathrm{C}$ and $65 \mathrm{~mm}$, respectively, and annual precipitation of approximately $1500 \mathrm{~mm}$ distributed between October and March [37,38].

The pedology is composed predominantly of red and red-yellow Oxisols, in addition to Inceptisols and Entisols [39-41]. The geology features the Slate Unit, an expressive set of purple, homogeneous, folded slates, with strong ardosian cleavage and occasional quartzite lenses, and the Sandy Metarrithmite Unit, irregular intercalations of fine and white quartzites with layers of metasiltstone [42]. In the FAL, there are intergranular or porous aquifers (pores of soil and saprolite) and fractured aquifers (fractures and failures in rock) [43]. In this study, we focus on the porous aquifer, which is essential for maintaining the baseflow in drought and for the recharge of the deep fractured aquifer [43,44].

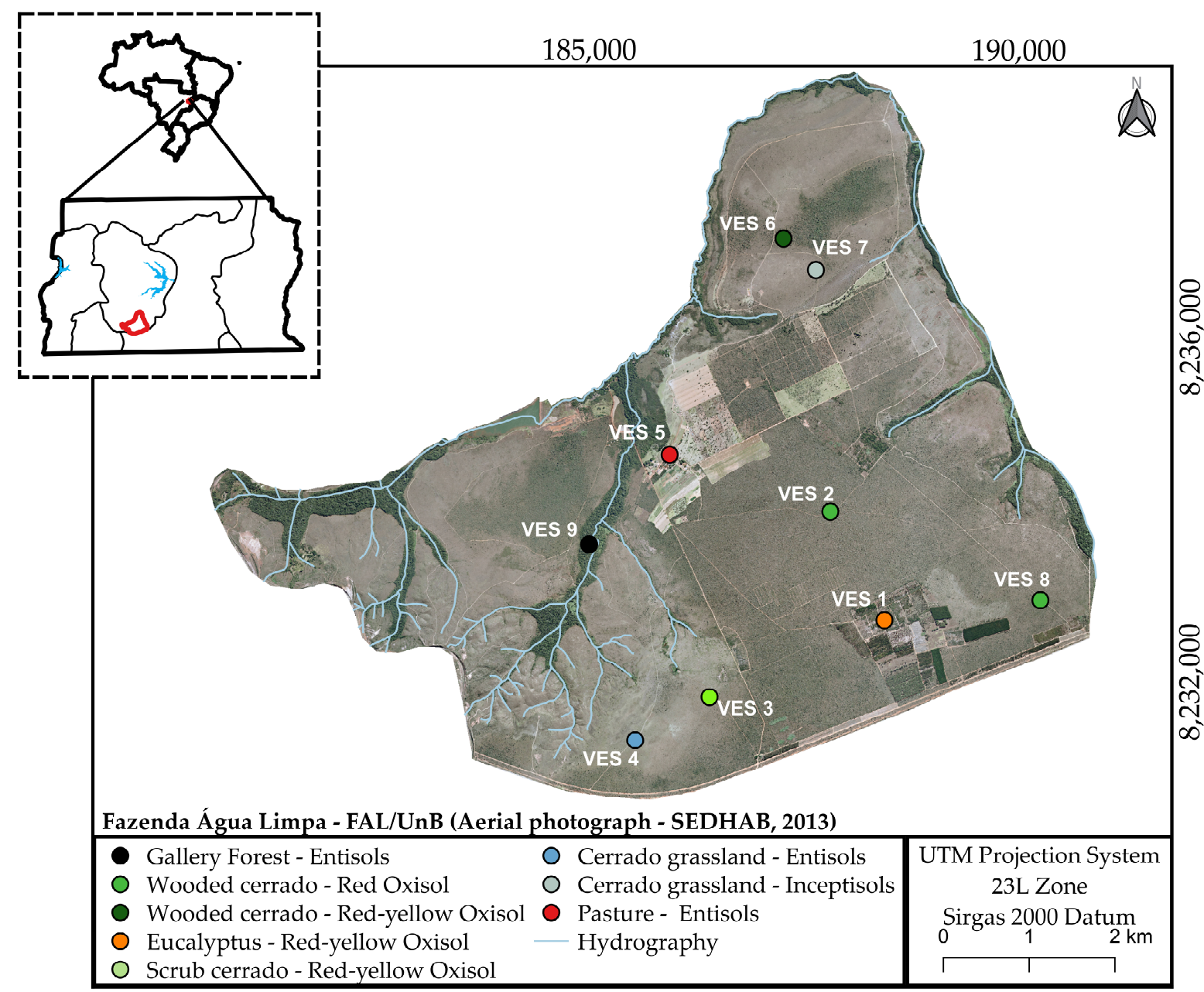

Figure 1. Fazenda Água Limpa (FAL/UnB), highlighted in red in the south-central portion of the Distrito Federal (DF), Brazil. Vertical electrical sounding (VES) locations in different pedological and land cover conditions, classified according to Natural Resources Conservation Service (NRCS); United States Department of Agriculture (USDA) [45] and Oliveira et al. [46], respectively. Aerial photograph provided by Secretaria de Habitação, Regularização e Desenvolvimento Urbano (SEDHAB) [47].

\subsection{Data Sets}

Analyzing the relationship between hydraulic and geoelectric parameters required data from vertical electrical sounding (VES), lithology, static water table level (WTL, $m$ ), groundwater electrical resistivity $\left(\rho_{\mathrm{w}}, \Omega \mathrm{m}\right)$, and slug tests (Figure $\left.\mathrm{S} 1\right)$. We defined nine VES stations close to groundwater monitoring wells (MW), encompassing different soils and phytophysiognomies representative of the Brazilian savannah (Figure 1). 
VES data were obtained between November 2019 and January 2020 with Schlumberger array, yielding the apparent electrical resistivity $\left(\rho_{\mathrm{a}}, \Omega \mathrm{m}\right)$ at different depths of the soil. Maximum spacing between current electrodes (A and B) was equal to $200 \mathrm{~m}$, and spacing between potential electrodes ( $\mathrm{M}$ and $\mathrm{N}$ ) varied from 0.4 to $12 \mathrm{~m}$.

The lithological data are from textural descriptions of the borehole core used for the installation of eight MWs. For MW 9, installed before this study, lithological data were not available. Visual and analytical interpretation of borehole samples allowed the definition of the predominant textural soil classes (sandy clay, silty clay, loam, sandy loam, clay loam, and silty loam) [48].

An electric sensor provided the measurement of the WTL, in all MWs simultaneously with VES. We assumed that $\rho_{\mathrm{W}}$ was the inverse of electrical conductivity $\left(\rho_{\mathrm{W}}=\sigma_{\mathrm{W}}{ }^{-1}, \sigma_{\mathrm{W}}\right.$ in Siemens) measured in groundwater samples collected in all MWs [24]. Recovery slug test data [49], analyzed with $R$ packages, provided the field values of the aquifer hydraulic parameters (saturated hydraulic conductivity $\mathrm{K}_{\mathrm{obs}}, \mathrm{m} \mathrm{s}^{-1}$, and transmissivity, $\mathrm{T}_{\mathrm{obs}}, \mathrm{m}^{2} \mathrm{~s}^{-1}$ ) in seven MWs. MWs 3 and 8 were dry during the period of carrying out the slug tests, so they do not present $\mathrm{K}_{\mathrm{obs}}$ and $\mathrm{T}_{\mathrm{obs}}$ data.

\subsection{VES Interpretation}

The $\rho_{\mathrm{a}}$ values plotted as a function of the AB/2 resulted in field curves for each VES station. The identification of the real resistivity $\left(\rho_{\text {aquifer }}, \Omega \mathrm{m}\right)$ and thickness $\left(\mathrm{h}_{\mathrm{aquifer}}, \mathrm{m}\right)$ of the aquifer from the field curves required (i) inversion of the field data; (ii) elaboration of the geoelectric models; and (iii) verification of the geoelectric models' ability to represent the saturated formation (Figure S1). We inverted VES data and elaborated on the geoelectric models using IPI2Win, which is a software to solve the regularization of nonlinear inversion problems by Tikhonov's approach [50].

Initially, VES data were automatically inverted, using a variant of the Newton algorithm [50] (Figure S1). This inversion provided the parameters for building the initial geoelectric model (resistivity, $\rho$, and thickness, $h$, of the geoelectric layers) by fitting a synthetic curve to the field curve. As the fit objective function, we inimized the Mean Absolute Percentage Error (MAPE) (Equation (1)) between field $\left(\rho_{a_{o} b s}\right)$ and synthetic $\left(\rho_{a_{c a l}}\right)$ data $[50,51]$.

$$
\operatorname{MAPE}(\%)=100 \times \frac{\sum_{\mathrm{i}=1}^{\mathrm{n}}\left(\ln \left(\frac{\rho_{a_{\text {obs }, i}}}{\rho_{a_{c a l, i}}}\right)\right)^{2}}{\mathrm{n}}
$$

It is important to note that inverse problems can present non-unique solutions. As a result, geoelectric models are subject to ambiguous interpretations that can cause inconsistency in the analyses derived from the $\rho_{\text {aquifer }}$ and $h_{\text {aquifer }}$ data $[24,52]$. To overcome this non-uniqueness problem, we associate available monitoring well (MW) data (lithology and WTL) to optimize the configuration of the geoelectric layers in the subsurface [53,54]. Initially, we compare layer thickness of the models resulting from the automatic inversion with lithological data.

To improve the representation of the subsurface layers, we inverted the VES data again, but in a semi-automatic way, when geoelectric models were not consistent with the lithological data and presented MAPE above 6\% (Figure S1). In this case, from the geoelectric model initially proposed, we adjust the parameters $\rho$ and $\mathrm{h}$ based on the lithological layers, resulting in geophysical-lithological models. In addition, WTL data allowed us to assess the correspondence between the position of the aquifer geoelectric layer and the real position of the aquifer in the subsurface. Lastly, we selected the saturated layer with reduced resistivity and that matched the position of the WTL, to represent the aquifer in each VES station (Figure S1).

\subsection{Geoelectric Aquifer Parameters Selection}

The results obtained from interpretations of the apparent resistivity field data $\left(\rho_{\mathrm{a}}\right)$ yielded the thickness $(\mathrm{h})$ and resistivity $(\rho)$ of subsurface layers. As previously defined, 
among the geoelectric subsurface layers of each VES station, we selected the resistivity and thickness data only from aquifer layer ( $\rho_{\text {aquifer }}$ and $h_{\text {aquifer }}$, respectively). Values of the $\rho_{\text {aquifer }}, \mathrm{h}_{\text {aquifer }}$, and $\rho_{\mathrm{w}}$ allowed the calculation of the formation factor $(\mathrm{F}$, dimensionless, also called intrinsic formation factor) and Dar Zarrouk parameters for porous aquifer in this study (Figure S1).

According to Archie's first law [10], beyond $\rho_{\mathrm{W}}, \rho_{\text {aquifer }}$ in porous formation depends on $\mathrm{F}$ (dimensionless) (Equation (2)), which represents the influence of formation characteristics, especially effective porosity percentage $(\varnothing)$ and intrinsic permeability $(k)$, in the electrical flow in a porous medium (Equation (3)). Because it depends on porosity and permeability, $\mathrm{F}$ has been inversely related to $\mathrm{K}$ in saturated porous formations (Equation (2)) $[2,4,12,19,24]$. In addition, the $\mathrm{F}$ estimate considers the cementation (m) and pore geometry $(\alpha)$ coefficients as characteristics of the medium that can influence the electrical flow [10]. Despite variables, in general $\mathrm{m}$ and $\alpha$ are equivalent to 2 and 1 , respectively $[10,24,36]$.

$$
\begin{gathered}
\rho_{\text {aquifer }}=\mathrm{F} \cdot \rho_{w} \\
\mathrm{~F}=\frac{\rho_{\text {aquifer }}}{\rho_{w}}=\alpha \cdot \varnothing^{-\mathrm{m}}
\end{gathered}
$$

Archie's first law applies mainly to clay-free mediums, because clay content involves simultaneously permeability reduction and decrease in the resistivity of the medium, by adding superficial and intrinsic electrical conductivity $[10,23,36,55]$. Therefore, for clay formations, such as those that predominate in our study area, F (Equation (3)) can vary with electrolyte concentration and would be more appropriately designated as apparent formation factor $\left(F_{a}\right)$, that considers the effect of clay conductivity $[9,13,36]$. However, in tropical soils, high weathering and leaching reduce the cation exchange capacity (CEC) and, consequently, limit the effect of surface electrical conductivity and make the soil structure equivalent to the sand soil [36,56-58]. Thus, we calculate F using Archie's Law in a similar way to clay-free soils.

In addition to $\mathrm{F}$, we estimated the Dar Zarrouk parameters, that is, transverse resistance ( $\mathrm{R}, \Omega \mathrm{m}^{2}$ ) and longitudinal conductance (C, Siemens) [11]. R indicates the electrical transverse resistance perpendicular to the soil layers and $C$ represents the conductance offered to current lines parallel to the soil layers (Equations (4) and (5)). R and C can indicate the protection capacity and transmissivity of the aquifer, respectively, and therefore are commonly related to $\mathrm{K}$ and $\mathrm{T}$ in porous aquifers $[8,17,34]$.

$$
\begin{gathered}
\mathrm{R}=\rho_{\text {aquifer }} \cdot \mathrm{h}_{\text {aquifer }} \\
\mathrm{C}=\frac{\mathrm{h}_{\text {aquifer }}}{\rho_{\text {aquifer }}}
\end{gathered}
$$

\subsection{Relationship between Hydraulic and Geoelectric Aquifer Parameters}

It is possible to relate aquifer geoelectric ( $\rho_{\text {aquifer }}, \mathrm{F}, \mathrm{R}$, and $\left.\mathrm{C}\right)$ and hydraulic parameters $\left(\mathrm{K}_{\mathrm{obs}}\right.$ and $\mathrm{T}_{\mathrm{obs}}$ ) considering (i) that electric current and water flow through the path of least resistance; and (ii) that in porous aquifers, this path is represented by the soil pores $[4,6,8]$. Based on these premises, we proposed empirical exponential regression models between $\mathrm{K}_{\mathrm{obs}}$ and $\rho_{\text {aquifer }}, \mathrm{K}_{\mathrm{obs}}$ and $\mathrm{F}, \mathrm{T}_{\mathrm{obs}}$ and $\rho_{\text {aquifer }}$, and $\mathrm{T}_{\mathrm{obs}}$ and $\mathrm{R}$ and $\mathrm{C}$, according to Akhter and Hasan, Khalil et al., Choo et al. and Diaz-Curiel et al. [2,6,20,23] (Figure S1). The nls (nonlinear least squares) function, available in the R program [59], allowed the estimation of the parameters of the exponential models by the nonlinear least squares method, which minimizes the sum of squared residuals (error) (SSR) between the observed data and the adjusted nonlinear function [60]. Relations that showed satisfactory adjustment $\left(R^{2}\right.$ greater than 0.5 and $p$-value less than 0.05 ) were used to estimate the hydraulic parameters (hydraulic conductivity $\mathrm{K}_{\mathrm{est}}, \mathrm{m} \mathrm{s}^{-1}$, and transmissivity, $\mathrm{T}_{\mathrm{est}}, \mathrm{m}^{2} \mathrm{~s}^{-1}$ ).

$\mathrm{T}$ was also estimated as the product between $\mathrm{h}_{\text {aquifer }}$ and $\mathrm{K}_{\mathrm{obs}}$ [24,34]. In addition to the estimates obtained through the empirical relationships proposed in this study, we determined 
$\mathrm{K}\left(\mathrm{m} \mathrm{s}^{-1}\right)$ and $\mathrm{T}\left(\mathrm{m}^{2} \mathrm{~s}^{-1}\right)$ according to Heigold et al. [24] (Equation (6)) and Niwas and Singhal [8] (Equation (7)), respectively, which consist of models widely used in porous aquifers (Figure S1). To estimate T, we used an average value of $\mathrm{K}_{\mathrm{obs}} \times \rho_{\text {aquifer }}[8,34]$, considered constant for the same soil type (Entisol $=6.69 \times 10^{-3} \Omega \mathrm{m}^{2} \mathrm{~s}^{-1}$, Oxisol $=7.53 \times 10^{-3} \Omega \mathrm{m}^{2} \mathrm{~s}^{-1}$, Inceptisol $\left.=1.02 \times 10^{-2} \Omega \mathrm{m}^{2} \mathrm{~s}^{-1}\right)$, with $\mathrm{K}_{\mathrm{obs}}$ in $\mathrm{m} \mathrm{s}^{-1}$ and $\rho_{\text {aquifer }}$ in $\Omega \mathrm{m}$, and a $\mathrm{C}(1 / \Omega$ or Siemens) value for each VES station.

Then, the consolidated model results $[8,24]$ were validated against the $K_{o b s}$ and $T_{o b s}$, determined in the field by means of a slug test. Considering that there is a significant relationship ( $\mathrm{R}^{2}$ greater than 0.5 and $p$-value less than 0.05$)$, we defined $\mathrm{K}_{\mathrm{obs}}$ according to Heigold et al. [24] and $\mathrm{T}_{\text {obs' }}$ according to Niwas and Singhal [8] as an approximation of the field data, and we used them to verify the empirical relationships proposed in this study. Match between $\mathrm{K}_{\mathrm{obs}}$ and $\mathrm{K}_{\text {est }}$ values and $\mathrm{T}_{\mathrm{obs}}$ and $\mathrm{T}_{\text {est }}$ values was assessed by linear regression models using $\mathrm{lm}$ function, available in the $\mathrm{R}$ program, [61] ( $\mathrm{R}^{2}$ greater than 0.5 and $p$-value less than 0.05) (Figure S1). Besides that, due to the unavailability of $\mathrm{K}$ and $\mathrm{T}$ data specific to the area of study, results obtained with the empirical models proposed in this study were compared against the $\mathrm{K}$ and $\mathrm{T}$ values available in the scientific literature, for similar hydrogeological conditions [41,62].

$$
\begin{gathered}
\mathrm{K}=386.40 \cdot \rho_{\text {aquifer }}{ }^{-0.93283} \\
\mathrm{~T}=\overline{\mathrm{K}_{\mathrm{obs}} \cdot \rho_{\text {aquifer }}} \cdot \mathrm{C}
\end{gathered}
$$

\section{Results and Discussion}

\subsection{Identification and Characterization of the Porous Aquifer}

The analysis of the $\rho_{\mathrm{a}}$ data allowed the characterization of the subsurface, using the values of $\rho$ and $\mathrm{h}$ of the soil layers, and the identification of the porous aquifer in each VES station. (Table 1, Figures 2 and 3). Synthetic curves (Figure 2) fitted to field data ( $\rho_{\mathrm{a}}$ at different depths of research), and the geophysical-lithological models derived from them (Table 1), revealed geoelectric patterns between VES stations with the same soil type (Figure 2).

There were similarities in the shape of the synthetic curves in VES 1, 2, 3, 6, and 8 (Figure 2A), characterized by the occurrence of Oxisols, and in VES 4, 5, and 9 (Figure 2B), located under Entisols. VES 7, positioned in an Inceptisol, presented a synthetic curve different from the other VES stations (Figure 2B). The inversion of the VES data together with lithological and WTL data resulted in geophysical-lithological models composed of five geoelectric layers, with MAPE below 6\% (Table 1, Figure 3).

Table 1. Results of the geoelectric model, with mean absolute percentage error (MAPE), and water table level (WTL) in the

\begin{tabular}{|c|c|c|c|c|c|c|c|c|c|c|c|c|c|}
\hline \multirow{2}{*}{$\begin{array}{c}\text { VES } \\
\text { Stations }\end{array}$} & \multirow{2}{*}{$\begin{array}{c}\text { Latitude } \\
\left({ }^{\circ} \mathrm{W}\right)\end{array}$} & \multirow{2}{*}{$\begin{array}{c}\text { Longitude } \\
\quad\left({ }^{\circ} \mathrm{S}\right)\end{array}$} & \multicolumn{5}{|c|}{ Electrical Resistivity $(\Omega \mathrm{m})$} & \multicolumn{4}{|c|}{ Thickness (m) } & \multirow{2}{*}{$\begin{array}{c}\text { RMS } \\
(\%)\end{array}$} & \multirow{2}{*}{$\begin{array}{c}\text { WTL } \\
\text { (m) }\end{array}$} \\
\hline & & & $\rho_{1}$ & $\rho_{2}$ & $\rho_{3}$ & $\rho_{4}$ & $\rho_{5}$ & $\mathrm{~h}_{1}$ & $\mathbf{h}_{2}$ & $\mathbf{h}_{3}$ & $\mathbf{h}_{4}$ & & \\
\hline VES 1 & $188,426.06$ & $8,232,711.67$ & 9500 & 12,500 & $4300 *$ & 22,000 & 7000 & 0.50 & 1.50 & $8.00 *$ & 8.00 & 4.50 & 9.50 \\
\hline VES 2 & $187,797.23$ & $8,233,971.49$ & 3400 & 24,000 & 1600 & $1000 *$ & 3200 & 0.50 & 1.00 & 12.00 & $7.00 *$ & 4.80 & 13.95 \\
\hline VES 3 & $186,380.77$ & $8,231,821.70$ & 8000 & 18,500 & 4300 & 3100 * & 7500 & 0.50 & 1.50 & 1.50 & $12.00 *$ & 4.85 & 9.80 \\
\hline VES 4 & $185,514.40$ & $8,231,319.81$ & 18,000 & 13,180 * & 31,400 & 3640 & 30,500 & 1.50 & $3.00^{*}$ & 3.50 & 6.00 & 5.95 & 2.00 \\
\hline VES 5 & $185,956.75$ & $8,234,689.66$ & 1700 & 800 & 2200 & 1000 * & 3200 & 0.50 & 2.00 & 5.00 & $9.00 *$ & 5.10 & 8.25 \\
\hline VES 6 & $187,132.65$ & $8,237,119.06$ & 7000 & 14,000 & 3200 & 1400 * & 3500 & 0.50 & 2.00 & 9.50 & $8.00 *$ & 5.95 & 12.40 \\
\hline VES 7 & $187,632.85$ & $8,236,764.72$ & 24,000 & 7500 & $4900 *$ & 6500 & 2200 & 1.50 & 1.50 & $7.00 *$ & 3.00 & 3.65 & 3.30 \\
\hline VES 8 & $190,328.84$ & $8,232,909.53$ & 9000 & 15,000 & 2500 & 1000 * & 3500 & 0.50 & 2.00 & 4.50 & $6.50 *$ & 4.20 & - \\
\hline VES 9 & $185,002.99$ & $8,233,698.99$ & 4500 & 3300 & 1900 * & 5000 & 3800 & 1.00 & 4.00 & $5.00 *$ & 10.00 & 4.25 & 9.25 \\
\hline
\end{tabular}
VES stations of the study area. 

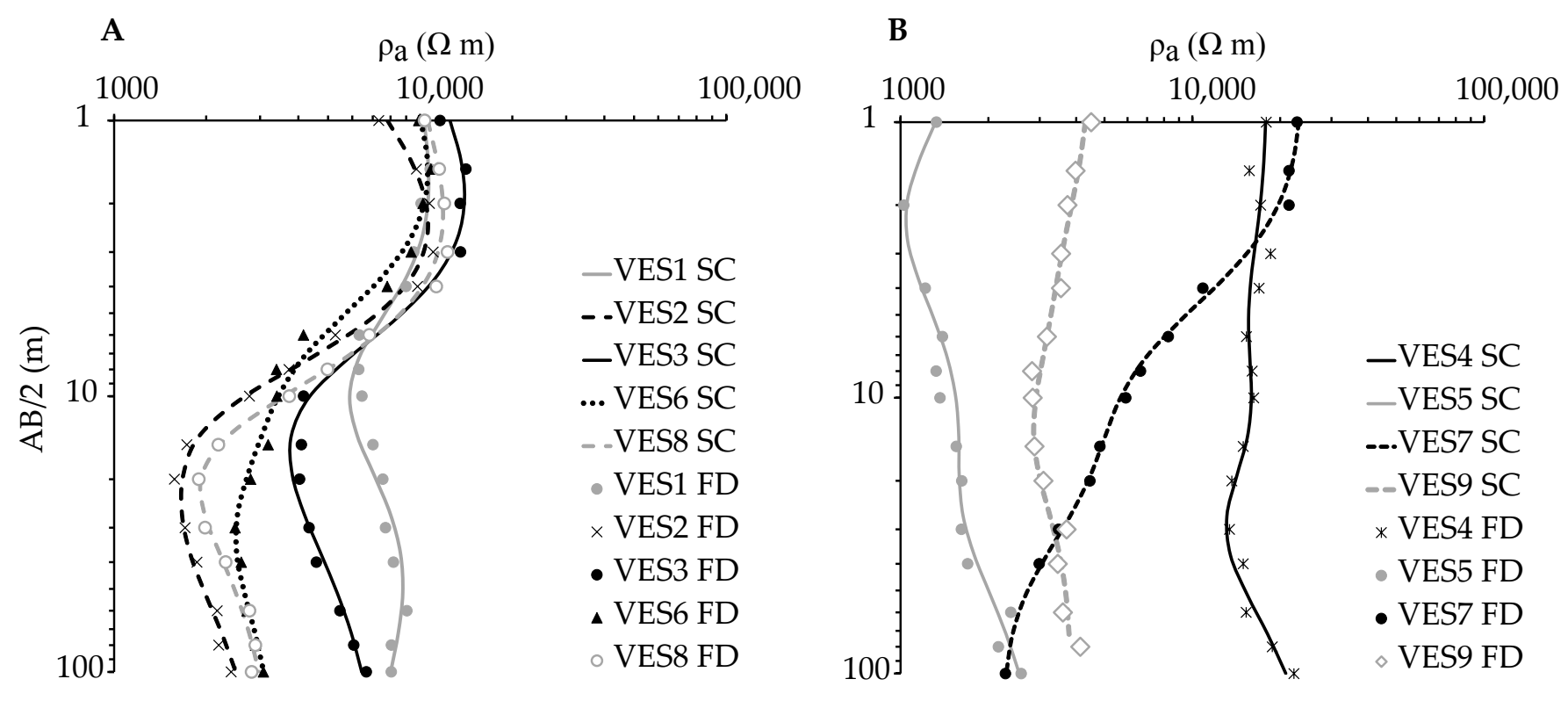

Figure 2. Vertical electrical sounding (VES) field data (FD) and synthetic curves (SC). The similar pattern between (A) VES sta-tions in an Oxisol (VES 1, 2, 3, 6, and 8) and (B) VES stations in an Entisol (VES 4, 5, and 9). VES 7, with Inceptisols, presented a different curve shape than the other VES stations. AB/2 represents an estimate of the theoretical depth of investigation.

$\mathrm{AB} / 2$, besides that representing the spacing between current electrodes ( $\mathrm{A}$ and $\mathrm{B}$ ), indicated adequate values of the theoretical depth of investigation for VESs, in comparison with field data (lithology and WTL) (Figures 2 and 3). Usually, AB/4 indicates the depth of investigation resulting from the VES [63], however, this relationship can be changed when there are field data that allow the evaluation and adjustment of the proposed geophysical models [64].

VES 1, 2, 3, 6, and 8 showed reduced values of resistivity in the first $0.50 \mathrm{~cm}$ of depth, followed by high values characteristic of the unsaturated zone of the soil, superimposed on the least resistive zone, possibly associated with the occurrence of aquifers (Figures 2 and 3). Finally, there was an increase in resistivity values, indicating a low permeability zone that supports the aquifer. (Figures 2 and 3). VES 7 demonstrated decreasing resistivity behavior, with an aquifer layer identified about $9 \mathrm{~m}$ deep (Table 1, Figures 2 and 3).

VES 4, 5, and 9 presented synthetic curves (Figure 2), and consequently, geophysicallithological models (Figure 3), with less expressive variations in resistivity along the soil profile compared to other VES stations. It is possible to infer that the moisture present in the soil profile, characteristic of Entisols, tends to standardize the resistivity values in the subsurface.

However, we still verified the occurrence of zones of lower resistivity indicative of the presence of an aquifer (Table 1). In VES 4 and 5 there were even two discontinuous layers of low resistivity, which may indicate the presence of two aquifer formations, the first associated with a suspended aquifer and the second representing a phreatic or confined aquifer.

VES station with the occurrence of gravel and sand in the soil profile showed high values of $\rho_{\text {aquifer }}$, as observed in VES 4 , while low $\rho_{\text {aquifer }}$ values were associated with the presence of clay, as in VES 2 (Figure 3) [15]. Nascimento et al. [65] indicated a directly proportional relationship between the clay and silt fraction and the moisture content. This aspect can be explained by the fact that in soil with a finer texture, the pores have smaller dimensions, and thus the moisture retention is more intense.

Regarding the identification of the aquifer, in VES 2, 4, 5, 6, and 7, the transition from layers with a high resistivity value to layers with reduced resistivity was approximated to 
the position of the water table (Figure 3). In the other vertical electrical sounding (VES) stations, although geophysical-lithological models does not indicate the exact depth of groundwater, the WTL was placed in layers with reduced electrical resistivity (Figure 3).

According to Martins et al. [66], the behavior of the conductive layer indicates the upper limit of the WTL, which can be interpreted as the transition between the soil cover and the underlying rock. For the VES 9 aquifer, the electrical resistivity value was equal to $1000 \Omega \mathrm{m}$. However, as the well remained dry during the rainy season, it was not possible to identify whether there was a relationship between the less resistive geoelectric layer and the aquifer formation in VES 9.
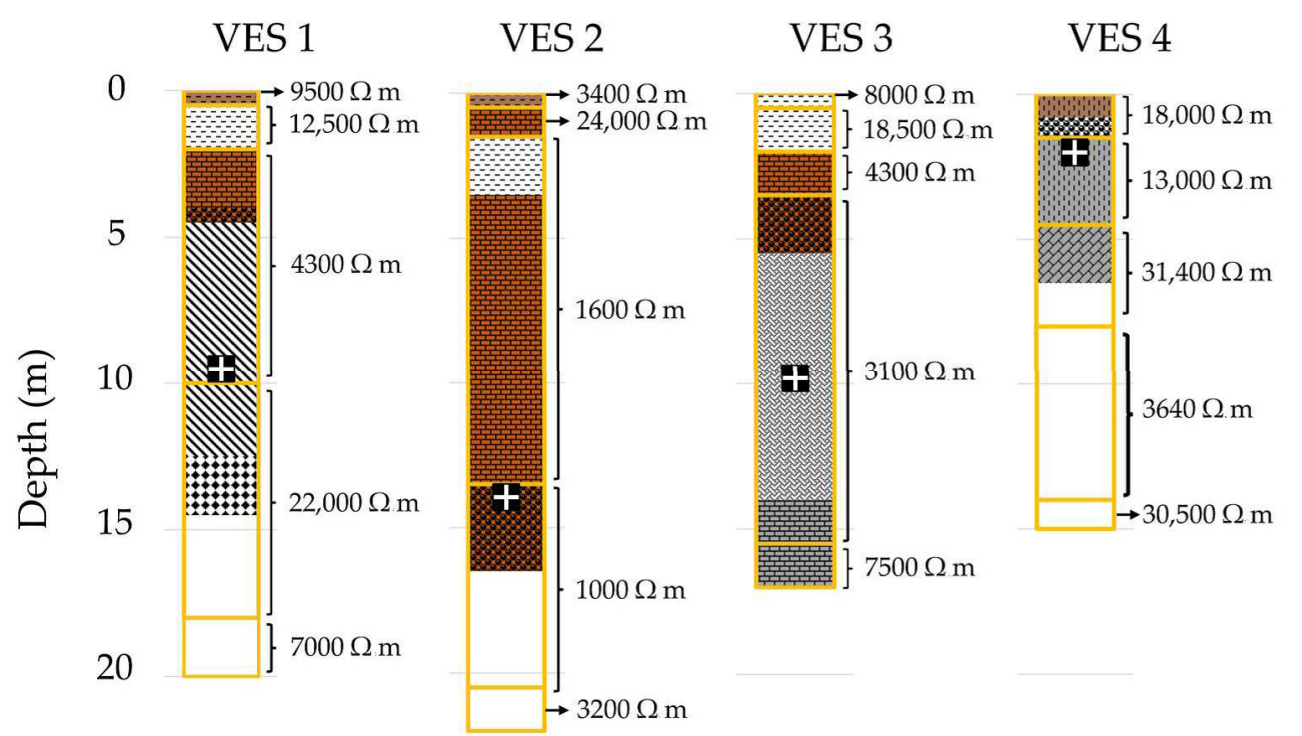

\section{5}

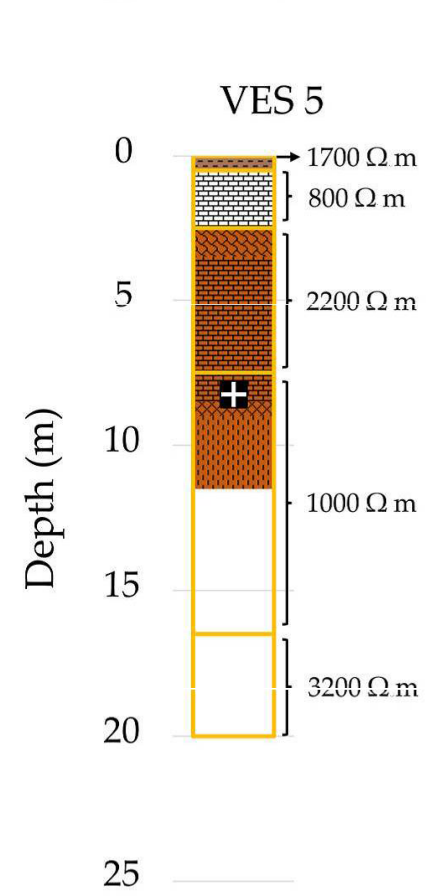

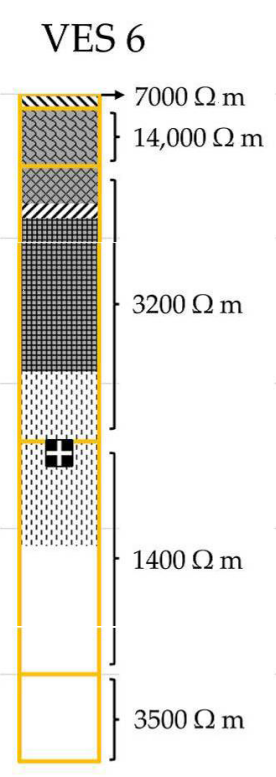

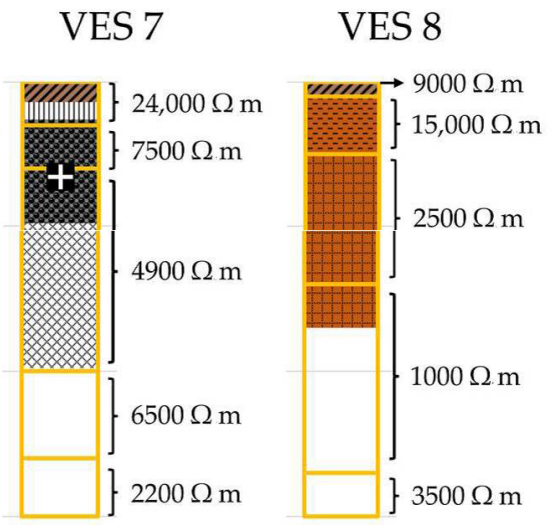

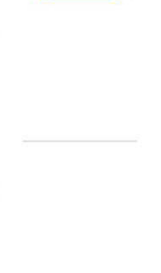

Lithology characterization
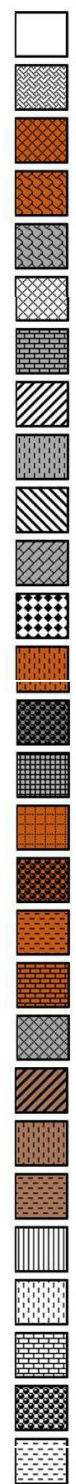

Undefined

Silty loam P

Clay loam R-Y M

Clay loam R-Y

Clay loam Y-Gr

Silty-clay loam P-Gr M

Silty-clay loam Sil P

Silty-clay loam Y-Gr M G

Sand-clay loam Gr M

Sand-clay loam $Y$

Sand loam Gr M

Loam $Y$

Silty clay R-Gr-Br

Silty clay Y-P-Br G

Silty clay $Y-G r$ M

Sand clay R-Gr

Sand clay R G

Sand clay $\mathrm{R}$

Sand clay R-Y

Sand clay P-Gr M

Sand clay Gr-Y M

Sand clay Br M

Sand clay Br

Sand clay Y-P-Br G

Sand clay Y-R M

Sand clay Y-R

Sand clay Y G

Sand clay $Y$

\section{Additional Symbology}

VES Layers

$\#$ WTL (m)

Figure 3. Geophysical-lithological models with inverted electrical resistivity and description of soil layers. $\mathrm{M}=$ mottled, $\mathrm{G}=$ gravel, $\mathrm{R}=$ red, $\mathrm{Y}=$ yellow, $\mathrm{Br}=$ brown, $\mathrm{P}=$ purple, $\mathrm{Gr}=$ grayish, $\mathrm{WTL}=$ water table level $(\mathrm{m})$. There were no lithology data for VES 9. 


\subsection{Relationship between the Geoelectric and Hydraulic Parameters of the Aquifer}

Geoelectric parameters of the porous aquifer, derived from the values of real $\rho_{\text {aquifer }}$ and $h_{\text {aquifer, }}$ allowed us to propose significant empirical relationships to estimate hydraulic parameters (K and T) through VES data (Figure 4, Table 2). Significant inverse relationships between $K_{\text {obs }}$ and $\rho_{\text {aquifer }}\left(R^{2}=0.90\right)$ and between $K_{\text {obs }}$ and $F\left(R^{2}=0.79\right)$, as we identified in this study, indicate porous media whose effective porosity equals soil water saturation [6,21] (Figure 4A,B). This result reinforces the predominant inverse pattern in the relationship between $\mathrm{K}$ and $\rho$ and between $\mathrm{K}$ and $\mathrm{F}$ for fully saturated aquifers, as observed in the scientific literature, making it possible to associate electrical and hydraulic conductivity in a porous medium [6,22].

Differently from the pattern observed in clayey sedimentary aquifers in temperate regions, the high concentration of clay, characteristic of granular aquifers in the study area, did not demonstrate a significant influence on the electrical and hydraulic behavior of the soil $[9,30,36]$. However, the non-unique relationship between $\mathrm{K}$ and $\rho$ and between $\mathrm{K}$ and $\mathrm{F}$ depends not only on the percentage of saturation and the concentration of clay in the aquifer $[6,23,28]$, but also on the cation exchange capacity and the particle size of the soil $[20,23,30]$. Oxisols, predominant in the study area, present granular structure in the homogeneous profiles, well developed, leached, and with reduced cation exchange capacity $[67,68]$. These factors favor the increase in hydraulic conductivity and, by analogy, electrical conductivity, similar to coarse-grained aquifers $[20,56,58]$.

Our results show that the $\mathrm{K}$ can be reasonably estimated with the information of surface geoelectric measurements. In this case, the reduced $\mathrm{K}$ values may be associated with a reduction in effective porosity, causing a reduction in the volume of intrapore water and, consequently, an increase in the $\rho_{\text {aquifer }}[2,6,20,21]$. It is important to note that the effective porosity represents the volume of connected pores and disregards the portion of the total porosity that remains isolated [1]. As a result, the effective porosity of the aquifer, also called electrical porosity, determines the flow of water and electrical current in the porous medium $[23,28]$.

The relationship between $\mathrm{T}_{\text {obs }}$ and $\rho_{\text {aquifer }}$ also resulted in a significant inverse exponential model $\left(R^{2}=0.63\right)$. A significant inverse relationship between $\rho$ and $T$ was also observed in a sandstone to limestone aquifer, located in the eastern desert of Egypt, being associated with the aquifer's high impedance to electric current, with increased resistivity due to the decrease in hydraulic conductivity and transmissivity [17]. Exponential regression models between $T$ and the parameters of Dar Zarrouk ( $R$ and $C$ ) resulted in non-significant inverse relationships ( $R^{2}$ less than 0.3 ) and, therefore, were not presented. It is possible that the high variability in the thickness of the aquifer layers for a reduced MW sample did not allow adequate association of the relationship between Dar Zarrouk parameters and T [29].

Both the hydraulic parameters determined by the slug test and estimated from the geoelectric parameters were considered representative of the soils of the study area, in comparison with the literature data [41,62]. We founded the highest $\mathrm{K}_{\mathrm{obs}}$ and $\mathrm{T}_{\mathrm{obs}}$ values in Oxisols, followed by Inceptisol and Entisol (Table 2). Regarding the parameters estimated by the relationships proposed in this study, Oxisols also showed higher $\mathrm{K}$ and $\mathrm{T}$ values compared to other soil types (Table 2). Differences in texture, structure, and macroporosity of these soils may explain variations observed in the values of the parameters [41]. In the case of Entisol, reduced $\mathrm{K}$ values are associated with reduced drainage capacity of the soil profile, which is permanently or seasonally soaked [62].

The verification of the results indicated a positive and significant linear relationship between $\mathrm{K}_{\text {est }}$ (Figure $4 \mathrm{E}$ ) and $\mathrm{T}_{\text {est }}$ (Figure $4 \mathrm{~F}$ ) from the empirical models proposed in this study and the results determined based on consolidated empirical models $\left(\mathrm{K}_{\mathrm{obs}}\right.$ and $\mathrm{T}_{\mathrm{obs}}{ }^{\prime}$ [8,24]. It is important to note that we previously evaluated the relationship between hydraulic parameters observed in the field and those estimated according to Heigold et al. [24] and Niwas and Singhal [8], and we obtained significant relationships $\left(R^{2}\right.$ above $0.5, p$-value $<0.05$ ) in both cases (Figure $4 C, D$ ). 

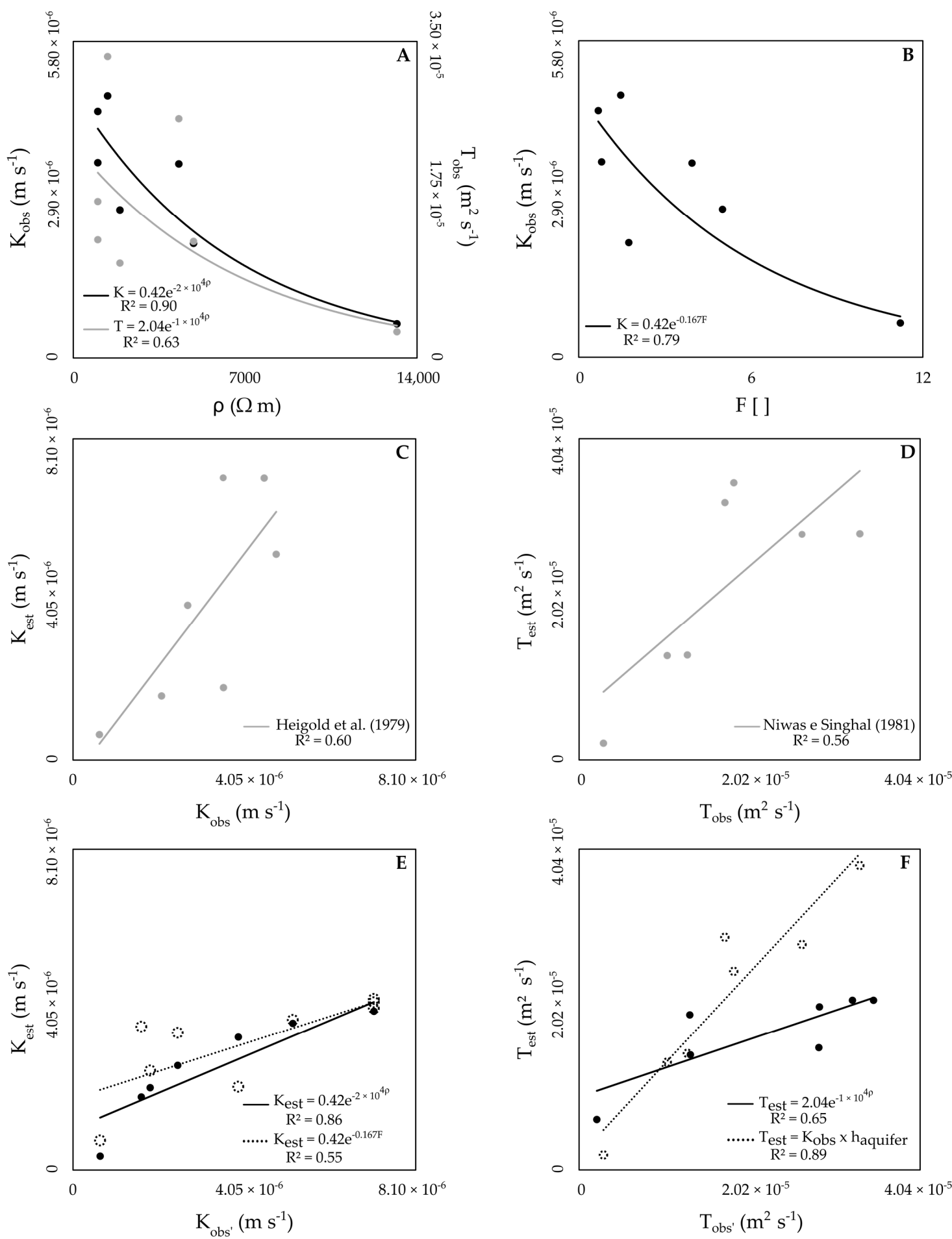

Figure 4. Relationship between geoelectric and hydraulic parameters in a porous aquifer. (A) Hydraulic conductivity ( $\left.\mathrm{K}_{\mathrm{obs}}\right)$ and transmissivity $\left(\mathrm{T}_{\mathrm{obs}}\right)$ values, obtained by slug test, as a function of the electrical resistivity values of the aquifer $\left(\rho_{\text {aquifer }}\right)$. (B) $\mathrm{K}_{\mathrm{obs}}$ as a function of the aquifer formation factor (F). (C) Comparison between the estimated hydraulic conductivity values $\left(\mathrm{K}_{\mathrm{est}}\right)$, according to Heigold et al. (1979) [24], and $\mathrm{K}_{\mathrm{obs}}$. (D) Comparison between the estimated transmissivity values ( $\mathrm{T}_{\text {est }}$ ), according to Niwas e Singhal (1981) [8], and $\mathrm{T}_{\mathrm{obs}}$. (E) Comparison between the estimated hydraulic conductivity values $\left(\mathrm{K}_{\mathrm{obs}^{\prime}}\right)$, according to Heigold et al. (1979) [24], and $\mathrm{K}_{\mathrm{est}}$ with equations presented in Figure 4A,B. (F) Comparison between the estimated transmissivity values $\left(\mathrm{T}_{\mathrm{obs}}\right)$, according to Niwas e Singhal (1981) [8], and $\mathrm{T}_{\text {est }}$ by equation in Figure $4 \mathrm{~A}$ and $\mathrm{K}_{\mathrm{obs}} \times \mathrm{h}_{\text {aquifer }}$. 


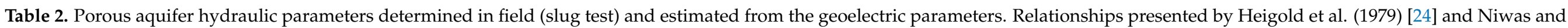
Singhal (1981) [8] allowed the evaluation of estimates using empirical relationships proposed in this study.

\begin{tabular}{|c|c|c|c|c|c|c|c|c|c|c|c|c|}
\hline \multirow[b]{2}{*}{$\begin{array}{c}\text { VES } \\
\text { Station }\end{array}$} & \multirow[b]{2}{*}{$\mathrm{K}_{\mathrm{obs}}\left(\mathrm{m} \mathrm{s}^{-1}\right)$} & \multirow[b]{2}{*}{$T_{o b s}\left(m^{2} s^{-1}\right)$} & \multirow[b]{2}{*}{$\rho_{\mathrm{w}}(\Omega \mathrm{m})$} & \multirow[b]{2}{*}{$\mathbf{F}$} & \multicolumn{2}{|c|}{ Dar Zarrouk Parameters } & \multicolumn{3}{|c|}{$K_{\text {est }}\left(\mathrm{m} \mathrm{s}^{-1}\right)$} & \multicolumn{3}{|c|}{$T_{\text {est }}\left(m^{2} s^{-1}\right)$} \\
\hline & & & & & $\begin{array}{c}\mathrm{C} \\
\text { (Siemens) }\end{array}$ & $\mathrm{R}\left(\Omega \mathrm{m}^{2}\right)$ & Model K1 * & Model K2 * & $\begin{array}{c}\text { Heigold et al. } \\
\text { (1979) }\end{array}$ & Model T1 * & Model T2 * & $\begin{array}{c}\text { Niwas and } \\
\text { Singhal } \\
\text { (1981) }\end{array}$ \\
\hline VES 1 & $3.56 \times 10^{-6}$ & $2.65 \times 10^{-5}$ & 1088.14 & 3.95 & $1.86 \times 10^{-3}$ & 34,400 & $2.07 \times 10^{-6}$ & $2.50 \times 10^{-6}$ & $1.82 \times 10^{-6}$ & $1.54 \times 10^{-5}$ & $2.85 \times 10^{-5}$ & $2.85 \times 10^{-5}$ \\
\hline VES 2 & $3.58 \times 10^{-6}$ & $1.84 \times 10^{-5}$ & 1250.00 & 0.80 & $7.00 \times 10^{-3}$ & 7000 & $4.01 \times 10^{-6}$ & $4.24 \times 10^{-6}$ & $7.11 \times 10^{-6}$ & $2.14 \times 10^{-5}$ & $2.51 \times 10^{-5}$ & $3.50 \times 10^{-5}$ \\
\hline VES 3 & $\mathrm{NA}^{*}$ & NA & 1540.83 & 2.01 & $3.87 \times 10^{-3}$ & 37,200 & $2.63 \times 10^{-6}$ & $3.46 \times 10^{-6}$ & $2.48 \times 10^{-6}$ & $1.74 \times 10^{-5}$ & NA & NA \\
\hline VES 4 & $6.25 \times 10^{-7}$ & $2.89 \times 10^{-6}$ & 1175.09 & 11.22 & $2.28 \times 10^{-4}$ & 39,540 & $3.51 \times 10^{-7}$ & $7.44 \times 10^{-6}$ & $6.42 \times 10^{-7}$ & $6.33 \times 10^{-6}$ & $1.88 \times 10^{-6}$ & $2.11 \times 10^{-6}$ \\
\hline VES 5 & NA & NA & 975.61 & 1.03 & $9.00 \times 10^{-3}$ & 9000 & $4.01 \times 10^{-6}$ & $4.08 \times 10^{-6}$ & $7.11 \times 10^{-6}$ & $2.14 \times 10^{-5}$ & NA & NA \\
\hline VES 6 & $4.80 \times 10^{-6}$ & $3.33 \times 10^{-5}$ & 954.20 & 1.47 & $5.71 \times 10^{-3}$ & 11,200 & $3.70 \times 10^{-6}$ & $3.79 \times 10^{-6}$ & $5.20 \times 10^{-6}$ & $2.06 \times 10^{-5}$ & $3.84 \times 10^{-5}$ & $2.85 \times 10^{-5}$ \\
\hline VES 7 & $2.09 \times 10^{-6}$ & $1.29 \times 10^{-5}$ & 2801.12 & 1.75 & $1.43 \times 10^{-3}$ & 34,300 & $1.84 \times 10^{-6}$ & $3.62 \times 10^{-6}$ & $1.62 \times 10^{-6}$ & $1.45 \times 10^{-5}$ & $1.47 \times 10^{-5}$ & $1.32 \times 10^{-5}$ \\
\hline VES 8 & $4.52 \times 10^{-6}$ & $1.73 \times 10^{-5}$ & 1464.13 & 0.68 & $6.50 \times 10^{-3}$ & 6500 & $4.01 \times 10^{-6}$ & $4.32 \times 10^{-6}$ & $7.11 \times 10^{-6}$ & $2.14 \times 10^{-5}$ & $2.94 \times 10^{-5}$ & $3.25 \times 10^{-5}$ \\
\hline VES 9 & $2.71 \times 10^{-6}$ & $1.05 \times 10^{-5}$ & 378.79 & 5.02 & $2.63 \times 10^{-3}$ & 9500 & $3.35 \times 10^{-6}$ & $2.10 \times 10^{-6}$ & $3.91 \times 10^{-6}$ & $1.96 \times 10^{-5}$ & $1.36 \times 10^{-5}$ & $1.31 \times 10^{-5}$ \\
\hline
\end{tabular}


Empirical and analytical models developed under specific conditions cannot be considered valid for other regions without prior evaluation $[8,24,28]$. Having satisfied this condition, we adopted the values derived from widely disseminated methods $[8,24]$ as a strategy to verify the results derived from the proposed empirical models, in order to evaluate the representation of hydraulic parameters for local conditions.

Despite the uncertainties associated with the process of determining the aquifer hydraulic parameters in the field, the collection and analysis of geophysical data, and the absence of field data to verify the estimated results, we emphasize the possibility of estimating hydraulic parameters in porous aquifers based on the geoelectric parameters, obtained through VES. The limitations described above are recommendations for future research, to improve the ability to indirectly estimate hydraulic parameters in porous aquifers and thus provide useful information for the process of planning and managing groundwater resources.

\section{Conclusions}

This study aimed to obtain indirect estimates of hydraulic parameters ( $\mathrm{K}$ and $\mathrm{T})$, using VES in an intergranular aquifer. Significant exponential regression models showed the possibility of using geoelectric parameters, obtained indirectly, to estimate hydraulic parameters ( $\mathrm{K}$ and $\mathrm{T}$ ) in porous aquifers. It is also worth mentioning the capacity of VES data for the delimitation of the porous aquifer. It is recommended that the proposed models be validated with field data, overcoming the limitations of the comparison between empirical models and methods in the literature adopted in this study. This study allowed the verification of the applicability of consolidated empirical models and the identification of appropriate empirical relationships for hydrogeological characterization in the Brazilian tropical porous aquifers. Regardless, the rapid sampling and low cost of performing VES, associated with the results obtained in this work, may justify the widespread use of this geophysical technique for preliminary characterization of porous aquifers, especially in regions absent of or with insufficient monitoring wells.

Supplementary Materials: The following are available online at https:/ /www.mdpi.com/2073-444 1/13/2/170/s1, Figure S1: Schematic representation of the data analysis steps.

Author Contributions: Conceptualization, A.d.A., C.T.C.N., and S.K.; methodology, A.d.A., C.T.C.N., and S.K.; formal analysis, A.d.A.; investigation, A.d.A., D.F.M., and K.F.S.; data curation, A.d.A., D.F.M., and K.F.S.; writing—original draft preparation, A.d.A.; writing—review and editing, A.d.A., C.T.C.N., S.K., D.F.M., and K.F.S.; supervision, C.T.C.N. and S.K. All authors have read and agreed to the published version of the manuscript.

Funding: This research was funded by Brazilian Coordination for the Improvement of Higher Education (CAPES), the Brazilian National Council for Scientific and Technological Development (CNPq), the Federal District Research Support Foundation (FAP-DF), and the University of Brasília (UnB), who granted the scholarship and research funding.

Data Availability Statement: The data presented in this study are available on request from the corresponding author. The data are not publicly available because it is part of a research project that has not yet been finished.

Acknowledgments: We would like to thank the Fazenda Água Limpa (FAL/UnB) for access to the area of study. In addition, we would like to thank the anonymous reviewers for their helpful advice and valuable comments on how to improve the manuscript.

Conflicts of Interest: The authors declare no conflict of interest.

\section{References}

1. Freeze, R.A.; Cherry, J.A. Groundwater; Prentice-Hall: Englewood Cliffs, NJ, USA, 1979.

2. Akhter, G.; Hasan, M. Determination of aquifer parameters using geoelectrical sounding and pumping test data in Khanewal District, Pakistan. Open Geosci. 2016, 8, 630-638. [CrossRef]

3. Fetter, C.W. Applied Hydrogeology, 3rd ed.; Macmillan College Publishing Company: New York, NY, USA, 1994.

4. Jones, P.H.; Buford, T.B. Electric Logging Applied to Ground-Water Exploration. Geophysics 1951, 16, 115-139. [CrossRef] 
5. Butler, J.J. Hydrogeological Methods for Estimation of Spatial Variations in Hydraulic Conductivity. In Hydrogeophysic; Springer: Berlin/Heidelberg, Germany, 2005; pp. 23-58. [CrossRef]

6. Khalil, M.A.; Monterio Santos, F.A. Influence of Degree of Saturation in the Electric Resistivity-Hydraulic Conductivity Relationship. Surv. Geophys. 2009, 30, 601-615. [CrossRef]

7. Brassington, R. Field Hydrogeology, 4th ed.; Wiley-Blackwell: Oxford, UK, 2017.

8. Niwas, S.; Singhal, D.C. Estimation of aquifer transmissivity from Dar-Zarrouk parameters in Porous Media. J. Hydrol. 1981, 50, 393-399. [CrossRef]

9. Worthington, P.F.; Barker, R.D. Methods for the calculation of true formation factors in the Bunter Sandstone of Northwest England. Eng. Geol. 1972, 6, 213-228. [CrossRef]

10. Archie, G.E. The electrical resistivity $\log$ as an aid in determining some reservoir characteristics. Pet. Trans. AIME 1942, 55, 9-16. [CrossRef]

11. Maillet, R. The fundamental equations of electrical prospectiong. Geophysics 1947, 12, 529-556. [CrossRef]

12. Oguama, B.E.; Ibuot, J.C.; Obiora, D.N. Geohydraulic study of aquifer characteristics in parts of Enugu North Local Government area of enugu state using electrical resistivity soundings. Appl. Water Sci. 2020, 10, 1-10. [CrossRef]

13. Wan Bakar, W.Z.; Mohd Saaid, I.; Ahmad, M.R.; Amir, Z.; Mahat, S.Q.A. Derivation of formation factor in shaly sandstone with geometry and clay conductivity effects. J. Pet. Sci. Eng. 2019, 182, 7. [CrossRef]

14. Tizro, A.T.; Voudouris, K.S.; Salehzade, M.; Mashayekhi, H. Hydrogeological framework and estimation of aquifer hydraulic parameters using geoelectrical data: A case study from West Iran. Hydrogeol. J. 2010, 18, 917-929. [CrossRef]

15. Mlangi, T.M.; Mulibo, G.D. Delineation of Shallow Stratigraphy and Aquifer Formation at Kahe Basin, Tanzania: Implication for Potential Aquiferous Formation. J. Geosci. Environ. Prot. 2018, 6, 78-98. [CrossRef]

16. Lech, M.; Skutnik, Z.; Bajda, M.; Markowska-Lech, K. Applications of Electrical Resistivity Surveys in Solving Selected Geotechnical and Environmental Problems. Appl. Sci. 2020, 10, 2263. [CrossRef]

17. Ammar, A.I.; Kamal, K.A. Effect of structure and lithological heterogeneity on the correlation coefficient between the electrichydraulic parameters of the Aquifer, Eastern Desert, Egypt. Appl. Water Sci. 2019, 9, 1-21. [CrossRef]

18. Virupaksha, H.S.; Lokesh, K.N. Electrical resistivity, remote sensing and geographic information system approach for mapping groundwater Potential Zones in Coastal Aquifers of Gurpur Watershed. Geocarto Int. 2019, 1-15. [CrossRef]

19. Zhu, L.; Gong, H.; Chen, Y.; Li, X.; Chang, X.; Cui, Y. Improved estimation of hydraulic conductivity by combining stochastically simulated hydrofacies with geophysical data. Sci. Rep. 2016, 6, 1-8. [CrossRef] [PubMed]

20. Choo, H.; Kim, J.; Lee, W.; Lee, C. Relationship between Hydraulic Conductivity and Formation Factor of Coarse-Grained Soils as a Function of Particle Size. J. Appl. Geophys. 2016, 127, 91-101. [CrossRef]

21. Moreira, C.A.; Cavalheiro, M.L.D.; Pereira, A.M.; Caron, F. Relações entre condutividade hidráulica, transmissividade, condutância longitudinal e sólidos totais dissolvidos para o aquífero livre de caçapava Do Sul (RS), Brasil. Eng. Sanit. Ambient. 2012, 17, 193-202. [CrossRef]

22. Rosa, F.T.; Moreira, C.A.; Carrara, A.; Dos Santos, S.F. Análise das relações entre resistividade elétrica, condutividade hidráulica e parâmetros físico-químicos para o aquífero livre da região de corumbataí (SP). Águas Subterrâneas 2017, 31, 384-392. [CrossRef]

23. Díaz-Curiel, J.; Biosca, B.; Miguel, M.J. Geophysical estimation of permeability in sedimentary media with porosities from 0 to 50\%. Oil Gas. Sci. Technol. 2015, 71. [CrossRef]

24. Heigold, P.C.; Gilkeson, R.H.; Cartwright, K.; Reed, P.C. Aquifer transmissivity from surficial electrical methods. Groundwater 1979, 338-345. [CrossRef]

25. Kwami, I.A.; Ishaku, J.M.; Mukkafa, S.; Haruna, A.I.; Ankidawa, B.A. Delineation of aquifer potential zones using hydraulic parameters in gombe and environs, North-Eastern, Nigeria. Heliyon 2019, 5, e01927. [CrossRef] [PubMed]

26. Ejiogu, B.C.; Opara, A.I.; Nwosu, E.I.; Nwofor, O.K.; Onyema, J.C.; Chinaka, J.C. Estimates of aquifer geo-hydraulic and vulnerability characteristics of imo state and environs, southeastern nigeria, using electrical conductivity data. Environ. Monit. Assess. 2019, 191, 1-19. [CrossRef] [PubMed]

27. Anosike, S.; Ibuot, J.C.; Obiora, D.N.; Ugbor, D.O. Geophysical and physicochemical investigation of groundwater repositories in Njaba LGA of Imo State, Eastern Nigeria. Int. J. Environ. Sci. Technol. 2019, 16, 8129-8140. [CrossRef]

28. Urish, D. Electrical resistivity-hydraulic conductivity relationships in glacial Outwash Aquifers. Water Resour. Res. 1981, 17, 3877-3879. [CrossRef]

29. Mazáč, O.; Kelly, W.E.; Landa, I. A Hydrogeophysical model for relations between electrical and hydraulic properties of aquifers. J. Hydrol. 1985, 79, 1-19. [CrossRef]

30. George, N.J.; Atat, J.G.; Umoren, E.B.; Etebong, I. Geophysical exploration to estimate the surface conductivity of residual argillaceous bands in the groundwater repositories of coastal sediments of EOLGA, Nigeria. NRIAG J. Astron. Geophys. 2017, 6, 174-183. [CrossRef]

31. Singh, S.; Singh, V.S. Estimation of hydraulic chracteristics of alluvial aquifers from electrical resistivity data. J. Geol. Soc. India 2016, 88, 77-86. [CrossRef]

32. Hasan, M.; Shang, Y.; Akhter, G.; Jin, W. Geophysical Assessment of Groundwater Potential: A Case Study from Mian Channu Area, Pakistan. Groundwater 2018, 56, 783-796. [CrossRef] 
33. Ekwe, A.C.; Opara, A.I.; Okeugo, C.G.; Azuoko, G.B.; Nkitnam, E.E.; Abraham, E.M.; Chukwu, C.G.; Mbaeyi, G. Determination of aquifer parameters from geosounding data in parts of Afikpo Sub-Basin, Southeastern Nigeria. Arab. J. Geosci. 2020, 13. [CrossRef]

34. Okiongbo, K.S.; Mebine, P. Estimation of Aquifer Hydraulic Parameters from Geoelectrical Method-A Case Study of Yenagoa and Environs, Southern Nigeria. Arab. J. Geosci. 2015, 8, 6085-6093. [CrossRef]

35. Mgbolu, C.C.; Obiadi, I.I.; Obiadi, C.M.; Okolo, C.M.; Irumhe, P.E. Integrated groundwater potentials studies, aquifer hydraulic characterisation and vulnerability investigations of parts of Ndokwa, Niger Delta Basin, Nigeria. Solid Earth Sci. 2019, 4, 102-112. [CrossRef]

36. Worthington, P.F. The uses and abuses of the archie equations, 1: The formation factor-porosity relationship. J. Appl. Geophys. 1993, 30, 215-228. [CrossRef]

37. Eiten, G. The cerrado vegetation of Brazil. Bot. Rev. 1972, 38, 201-341. [CrossRef]

38. Maia, J.M.F.; Baptista, G.M.M. Clima. In Águas Emendadas; Secretaria de Desenvolvimento Urbano e Meio Ambiente (SEDUH): Brasília, Brazil, 2008; pp. 101-110.

39. Assad, E.D.; Sano, E.E.; Meirelles, M.L.; Silva, F.A.M.; Moreira, L.; Macedo, J.; Resck, D.V.S.; Ker, J.C.; Chagas, C.S.; Carvalho-Junior, V. Caracterização Ambiental Da Microbacia Do Córrego Taquara, DF; EMBRAPA: Planaltina, Brazil, 1992.

40. Santos, H.G.; Jacomine, P.K.; Anjos, L.H.; Oliveira, V.A.; Lumbreras, J.F.; Coelho, M.R.; Almeida, J.A.; Cunha, T.J.; Oliveira, J.B. Sistema Brasileiro de Classificação de Solos; EMBRAPA: Brasília, Brazil, 2013. [CrossRef]

41. Gonçalves, T.D.; Lohe, C.; Campos, J.E.G. Hydraulic characterization from porous aquifers of the Brazilian federal district. Brazilian J. Geol. 2015, 45, 259-271. [CrossRef]

42. Freitas-Silva, F.H.; Campos, J.E.G. Geologia Do Distrito Federal. In Inventário Hidrogeológico e dos Recursos Hídricos Superficiais do Distrito Federal; IEMA/SEMATEC/UnB: Brasília, Brazil, 1998; p. 86.

43. Campos, J.E.G. Hidrogeologia Do Distrito Federal: Bases Para a Gestão Dos Recursos Hídricos Subterrâneos. Rev. Bras. Geociências 2004, 34, 41-48. [CrossRef]

44. Campos, J.E.G.; Freitas-Silva, F.H. Hidrogeologia Do Distrito Federal. In Inventário Hidrogeológico e dos Recursos Hídricos Superficiais do Distrito Federal; IEMA/SEMATEC/UnB: Brasília, Brazil, 1998.

45. NRCS; USDA. Keys to Soil Taxonomy; NRCS: USDA: Washington, DC, USA, 2014; Volume 12.

46. Oliveira, P.T.S.; Leite, M.B.; Mattos, T.; Nearing, M.A.; Scott, R.L.; de Oliveira Xavier, R.; da Silva Matos, D.M.; Wendland, E. Groundwater recharge decrease with increased vegetation density in the Brazilian Cerrado. Ecohydrology 2017, 10, 1-8. [CrossRef]

47. SEDHAB. Sicad-Sistema Cartográfico Do Distrito Federal Escala 1:10.000; Secretaria de Habitação, Regularização e Desenvolvimento Urbano: Brasília, Brazil, 2017.

48. EMBRAPA. Manual de Métodos de Análise de Solo; Centro Nacional de Pesquisa de Solos: Rio de Janeiro, Brazil, 1997.

49. Cooper, H.H.J.; Bredehoeft, J.D.; Papadopulos, I.S. Response of a Finite-Diameter Well to an Instantaneous Charge Water. Water Resour. Res. 1967, 3, 263-269. [CrossRef]

50. Bobachev, A.A.; Modin, I.N.; Shevin, V.A. IPI2Win: User's Guide; State University/Geoscan-M: Moscow, Russia, 2001.

51. Tofallis, C. A Better Measure of Relative Prediction Accuracy for Model Selection and Model Estimation. J. Oper. Res. Soc. 2015, 66, 1352-1362. [CrossRef]

52. Garofalo, F.; Sauvin, G.; Socco, L.V.; Lecomte, I. Joint inversion of seismic and electric data applied to 2D media. Geophysics 2015, 80, EN93-EN104. [CrossRef]

53. Simms, J.E.; Morgan, F.D. Comparison of Four Least-squares Inversion Schemes for Studying Equivalence in One-dimensional Resistivity Interpretation. Geophysics 1992, 57, 1282-1293. [CrossRef]

54. Attwa, M.; Akca, I.; Basokur, A.T.; Günther, T. Structure-based geoelectrical models derived from genetic algorithms: A case study for hydrogeological investigations along Elbe River Coastal Area, Germany. J. Appl. Geophys. 2014, 103, 57-70. [CrossRef]

55. Vinegar, H.J.; Waxman, M.H. Induced polarization of shaly sands-The effect of clay counterion type. Geophysics 1984, 49 , 1267-1287. [CrossRef]

56. Pincus, L.N.; Ryan, P.C.; Huertas, F.J.; Alvarado, G.E. The influence of soil age and regional climate on clay mineralogy and cation exchange capacity of moist tropical soils: A case study from late quaternary chronosequences in Costa Rica. Geoderma 2017, 308, 130-148. [CrossRef]

57. Alekseeva, T.V.; Sokolowska, Z.; Hajnos, M.; Alekseev, A.O.; Kalinin, P.I. Water stability of aggregates in subtropical and tropical soils (georgia and china) and its relationships with the mineralogy and chemical properties. Eurasian Soil Sci. 2009, 42, 415-425. [CrossRef]

58. Reneau, J.R.B.; Fiskell, J.G.A. Selective dissolution effects on cation-exchange capacity and specific surface of some tropical soil clays. Soil Sci. Soc. Am. J. 1970, 34, 809-812. [CrossRef]

59. Baty, F.; Ritz, C.; Charles, S.; Brutsche, M.; Flandrois, J.P.; Delignette-Muller, M.L. A toolbox for nonlinear regression in R: The package nlstools. J. Stat. Softw. 2015, 66, 1-21. [CrossRef]

60. Brandt, S. Data Analysis: Statistical and Computational Methods for Scientists and Engineers, 4th ed.; Springer: Siegen, Germany, 2014. [CrossRef]

61. R Core Team. R: A Language and Environment for Statistical Computing; R Foundation for Statistical Computing: Vienna, Austria, 2017. 
62. De Oliveira Fiori, J.P.; Campos, J.E.G.; Almeida, L. Variabilidade da condutividade hidráulica das principais classes de solos do estado de goiás. Geociencias 2010, 29, 229-235.

63. Barker, R.D. Depth of investigation of collinear symmetrical four-electrode arrays. Geophysics 1989, 54, 1031-1037. [CrossRef]

64. Braga, A.C.O. Geofísica Aplicada: Métodos Geoelétricos Em Hidrogeologia; Oficina de Textos: São Paulo, Brazil, 2016.

65. Nascimento, C.T.C.; Varella, R.F.; Pires, A.C.B.; Santos, R.V. Valores de resistividade elétrica em um latossolo do distrito federal. CISBGF 2001, 7, 289-292.

66. Martins, É.D.S.; de Carvalho Júnior, O.A.; Mello, G.D.A.; Reatto, A.; de Moraes, R.A.V.; Pires, A.C.B.; Guimarães, R.F. Mapeamento da superfície basal do manto de intemperismo pelo comportamento da resistidade elétrica do distrito federal. Rev. Bras. Geomorfol. 2008, 9, 15-28. [CrossRef]

67. Ker, J.C. Latossolos do Brasil: Uma revisão. Geonomos 1997, 5, 17-40. [CrossRef]

68. Alvarenga, M.I.N.; Davide, A.C. Características físicas e químicas de um latossolo vermelho-escuro e a sustentabilidade de agroecossistemas. Rev. Bras. Ciência Solo 1999, 23, 933-942. [CrossRef] 